\title{
Thyroid Autoimmunity is a Risk Factor for Recurrent Pregnancy Loss
}

\author{
Sharmin Sultana ${ }^{1}$, Mosammat Nargis Shamima ${ }^{2}$, Sahela Jesmin ${ }^{3}$ \\ Nargis Zahan ${ }^{4}$, Md. Abu Zahid ${ }^{5}$, Mohd. Alamgir Hossain ${ }^{6}$, Shahin Mahmuda ${ }^{7}$
}

\begin{abstract}
This was a hospital based case control study. The study included patients attending in outdoor and indoor Department of Obstetrics and Gynaecology of Rajshahi Medical College, Hospital since July 2014 to June 2016.

The aim of this study was to determine thyroid antibodies is a risk factor for recurrent pregnancy loss. Sixty seven pregnant or non pregnant women with history of recurrent miscarriage during $1^{\text {st }}$ trimester were selected as case group and another sixty seven pregnant women who reached their 12 weeks uneventfully with no history of recurrent miscarriage were selected as control group. Patients with other cause of recurrent miscarriage such as metabolic or endocrinologic disorders, genital organ anomaly, uterine fibroid were excluded from the study. Thyroid function test and thyroid antibodies ( $\mathrm{FT}_{4}, \mathrm{TSH}$ and TPO-Ab) were measured for the two groups. The result of this study showed that the percentage of positive TPO-Ab in target and control group is $67.16 \%$ and $5.95 \%$ respectively.

The study observed that the mean serum concentrations of $\mathrm{FT}_{4}$ in the control subject was significantly higher than the mean of the target group ( $p$-value $<0.05)$. The TSH concentration was increased in miscarriage women with positive antibodies compared with the concentration of TSH in the control group with positive antibodies. The conclusions are that there is a deficiency in thyroid hormones or thyroid's functional capacity is unable to meet the extra demands of pregnancy which may be one of the causes of recurrent miscarriage. Moreover positive thyroid antibodies pregnant women can reach term and have babies when the concentration of TSH is low during the first trimester, so the risk of miscarriage could be high in positive thyroid antibodies.
\end{abstract}

Key words: Autoimmunity, TPO-Ab, Miscarriage, Thyroxin.

TAJ 2017; 30: No-1: 49-55

\section{Introduction}

Recurrent pregnancy loss is defined as three or more consecutive spontaneous pregnancy losses before 20 weeks of gestation. Pregnancy loss in the first trimester is the most common complication affecting approximately $15-20 \%$ of clinically recognized pregnancies. ${ }^{1}$ Potential amount of possible miscarriage before pregnancy is recognized to be about $30 \%$.

Recurrent miscarriage defined as loss of two or more consecutive pregnancies (ASRM practice

${ }^{1}$ Medical Officer, Department of Obs \& Gynae, Rajshahi Medical College Hospital, Rajshahi.

${ }^{2}$ Assistant Professor, Department of Obs \& Gynae, Rajshahi Medical College, Rajshahi.

3 Professor and Head, Department of Obs \& Gynae, Rajshahi Medical College, Rajshahi.

${ }^{4}$ Junior Consultant, Department of Obs \& Gynae, Rajshahi Medical College Hospital, Rajshahi.

${ }^{5}$ Assistant Professor, Department of Anaesthesiology, Rajshahi Medical College, Rajshahi.

${ }^{6}$ Assistant Professor, Department of Orthopaedic Surgery, Rajshahi Medical College, Rajshahi.

${ }^{7}$ Associate Professor, Department of Physiology, Rajshahi Medical College, Rajshahi. 
committee Report, 2008), occurs in $1-2 \%$ of couples attempting to bear children., ${ }^{2,3}$ Several disorders are associated with recurrent pregnancy loss. Diseases of the thyroid gland such as hypo and hyperthyroidism have also been associated with fetal loss. Over the past decade, many reports have linked thyroid autoimmunity (TA) with recurrent abortion and it has been suggested that thyroid auto antibodies may serve as a marker for at-risk pregnancies. ${ }^{4,5}$ Furthermore, it was recently shown that thyroxine administration to pregnant women with positive thyroid auto antibodies and a history of recurrent abortions may improve the outcome. ${ }^{6}$

Thyroid hormones are essential for the growth and metabolism of the growing fetus. Early in pregnancy, the mother supplies her fetus with thyroid hormones. The fetal thyroid gland is not fully functional until after 12 weeks. If the mother is hypothyroid, she cannot supply her fetus with enough thyroid hormones. Hence hypothyroidism is a risk factor for pregnancy loss. Thyroid disorder in early pregnancy may lead to grave consequences, and therefore testing may be appropriate. $^{7}$ The prevalence of sub-clinical hypothyroidism in women in the childbearing age may be as high as $5 \%{ }^{8,9}$ Hence, there is a need to screen for subclinical hypothyroidism and thyroid autoimmunity in pregnancy, especially in women with a history of miscarriage. Even minimal hypothyroidism can increase rates of miscarriage and fetal death and may also have adverse effects on later cognitive development of the offspring .The thyroid gland and gonadal axes interact continuously before and during pregnancy. Hypothyroidism influences ovarian function by decreasing levels of sex-hormone-binding globulin and increasing the secretion of prolactin. ${ }^{10}$

Pregnancy is also accompanied by immunologic changes, mainly characterized by a shift from a $\mathrm{T}$ helper-1 lymphocyte to a $\mathrm{T}$ helper-2 lymphocyte state. Thyroid peroxidase antibodies are present in $10 \%$ of women at 14 weeks' gestation, and are associated with (a) an increased pregnancy failure (i.e., abortion), (b) an increased incidence of gestational thyroid dysfunction, and (c) a predisposition to postpartum thyroiditis. ${ }^{11}$ During the first trimester, however, pregnant women with autoimmune thyroiditis (AITD) carry a significantly increased risk for miscarriage compared to women without AITD, even if euthyroidism. ${ }^{12}$ Presence of thyroid autoimmunity does not interfere with normal embryo implantation, but the risk of early miscarriage is substantially raised.

\section{Materials and Methods}

This is a case control study. Sixty seven pregnant or non pregnant women with history of recurrent miscarriage during $1^{\text {st }}$ trimester were selected as case group and another sixty seven pregnant women who reached their 12 weeks uneventfully with no history of recurrent miscarriage were selected as control group. This study was carried out in outdoor and indoor Department of Obstetrics and Gynaecology of Rajshahi Medical College Hospital, Rajshahi. The patients are selected by purposive sampling method.

\section{Results}

Table I: Distribution of the study patients by age (years) $(n=134)$

\begin{tabular}{|c|c|c|c|c|c|}
\hline \multirow{2}{*}{$\begin{array}{c}\text { Age } \\
\text { (years) }\end{array}$} & \multicolumn{2}{|c|}{$\begin{array}{l}\text { Target group } \\
\qquad(n=67)\end{array}$} & \multicolumn{2}{|c|}{$\begin{array}{l}\text { Control group } \\
\qquad(n=67)\end{array}$} & \multirow{2}{*}{$\begin{array}{c}\mathrm{P} \\
\text { value }\end{array}$} \\
\hline & $\begin{array}{c}\text { No. of } \\
\text { patients }\end{array}$ & $\%$ & $\begin{array}{c}\text { No. of } \\
\text { patients }\end{array}$ & $\%$ & \\
\hline $18-22$ & 13 & 19.4 & 19 & 28.36 & \multirow{4}{*}{0.35} \\
\hline $23-27$ & 17 & 25.37 & 23 & 34.32 & \\
\hline 28-32 & 26 & 38.81 & 15 & 22.39 & \\
\hline 33-37 & 11 & 16.42 & 10 & 14.93 & \\
\hline
\end{tabular}

Table I shows $38.81 \%$ patients were belonged to age 28 -32 years among cases and $34.32 \%$ of $23-27$ years age group in control. There is no significant difference.

Table I shows $38.81 \%$ patients were belonged to age $28-32$ years among cases and $34.32 \%$ of $23-27$ 
years age group in control. There is no significant difference.

Table II: Distribution of the study patients by BMI $\left(\mathrm{Kg} / \mathrm{m}^{2}\right)(\mathrm{n}=134)$

\begin{tabular}{|c|c|c|c|c|c|}
\hline \multirow{2}{*}{$\begin{array}{c}\text { BMI } \\
\left(\mathrm{Kg} / \mathrm{m}^{2}\right)\end{array}$} & \multicolumn{2}{|c|}{$\begin{array}{l}\text { Target group } \\
\quad(\mathrm{n}=67)\end{array}$} & \multicolumn{2}{|c|}{$\begin{array}{l}\text { Control group } \\
\quad(n=67)\end{array}$} & \multirow{2}{*}{$\begin{array}{c}\mathrm{P} \\
\text { value }\end{array}$} \\
\hline & $\begin{array}{c}\text { No. of } \\
\text { patients }\end{array}$ & $\%$ & $\begin{array}{c}\text { No. of } \\
\text { patien } \\
\text { ts }\end{array}$ & $\%$ & \\
\hline $\begin{array}{c}\text { 18.5- } \\
22.99 \\
\text { (normal) }\end{array}$ & 12 & 17.91 & 27 & 40.29 & \multirow{2}{*}{0.04} \\
\hline $\begin{array}{l}\geq 23.0 \\
\text { (over } \\
\text { wt) }\end{array}$ & 55 & 82.09 & 40 & 59.71 & \\
\hline
\end{tabular}

$\mathrm{P}$ value reached from chi square test.

Table II shows $82.09 \%$ patients had BMI $\geq 23.0$ $\mathrm{kg} / \mathrm{m}^{2}$ among cases and $59.71 \%$ in controls. There is no significant difference.

Table III: Distribution of the study patients by TSH $(n=134)$

\begin{tabular}{|c|c|c|c|c|c|}
\hline & $\begin{array}{l}\text { Target } \\
\text { group } \\
(\mathrm{n}=67)\end{array}$ & $\begin{array}{c}\text { Control } \\
\text { group } \\
(\mathrm{n}=67)\end{array}$ & $\begin{array}{c}\mathrm{P} \\
\text { value }\end{array}$ & $\begin{array}{l}\text { 95\% CI } \\
\text { (Lower, } \\
\text { Upper) }\end{array}$ & OR \\
\hline & $\begin{array}{c}\text { No. of } \\
\text { patients }\end{array}$ & $\begin{array}{c}\text { No. of } \\
\text { patients }\end{array}$ & & & \\
\hline Raised & 25 & 10 & \multirow[b]{2}{*}{0.03} & \multirow[b]{2}{*}{$\begin{array}{l}1.47, \\
7.81\end{array}$} & \multirow[b]{2}{*}{3.39} \\
\hline $\begin{array}{c}\text { Normal } \\
(0.3-5.0)\end{array}$ & 42 & 57 & & & \\
\hline
\end{tabular}

Table III shows raised TSH level compared to normal TSH level is 3.39 times more likely to have recurrent pregnancy loss with 95\% CI 1.47$7.81 \%$. The difference was significant $(p<0.05)$ between two groups.
Table IV: Distribution of the study patients by mean TSH level $(n=134)$

\begin{tabular}{|c|c|c|c|}
\hline \multirow{2}{*}{ TSH level } & $\begin{array}{c}\text { Target group } \\
(\mathrm{n}=67)\end{array}$ & $\begin{array}{c}\text { Control group } \\
(\mathrm{n}=67)\end{array}$ & P value \\
\cline { 2 - 4 } & Mean $\pm \mathrm{SE}$ & Mean $\pm \mathrm{SE}$ & \\
\hline $\begin{array}{c}\mathrm{TSH} \\
(\mu \mathrm{lU} / \mathrm{ml})\end{array}$ & $4.31 \pm 2.74$ & $2.56 \pm 0.89$ & \multirow{2}{*}{0.02} \\
\hline $\begin{array}{c}\text { Range } \\
(\mathrm{min}, \mathrm{max})\end{array}$ & $0.79,12.98$ & $1.01,6.48$ & \\
\hline
\end{tabular}

Mean TSH level was found $4.31 \pm 2.74 \mu \mathrm{IU} / \mathrm{ml}$ in target group and $2.56 \pm 0.89 \mu \mathrm{IU} / \mathrm{ml}$ in control group. The mean difference was significant $(p<0.05)$ between two groups.

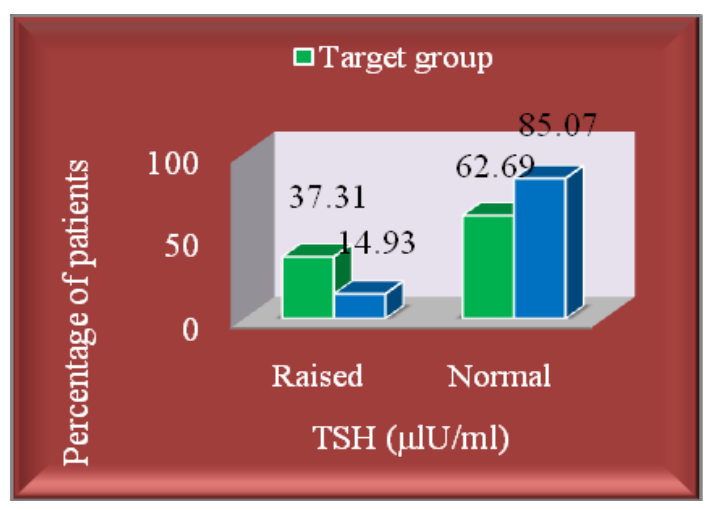

Figure 1: Bar diagram showing TSH level of the patients.

Table V: Distribution of the study patients by $\mathrm{FT}_{4}$ $(\mathrm{n}=134)$

\begin{tabular}{|c|c|c|c|c|c|}
\hline \multirow{2}{*}{$\begin{array}{c}\mathrm{FT}_{4} \\
(\mathrm{fmol} / \\
\mathrm{ml})\end{array}$} & $\begin{array}{l}\text { Target } \\
\text { group } \\
(\mathrm{n}=67)\end{array}$ & $\begin{array}{c}\text { Control } \\
\text { group } \\
(n=67)\end{array}$ & \multirow{2}{*}{$\begin{array}{c}\mathrm{P} \\
\text { value }\end{array}$} & \multirow{2}{*}{$\begin{array}{c}95 \% \text { CI } \\
\text { (Lower, } \\
\text { Upper) }\end{array}$} & \multirow{2}{*}{ OR } \\
\hline & $\begin{array}{c}\text { No. of } \\
\text { patient } \\
\text { s }\end{array}$ & $\begin{array}{c}\text { No. of } \\
\text { patients }\end{array}$ & & & \\
\hline Low & 48 & 5 & 0.001 & 10.91, & 31.33 \\
\hline
\end{tabular}




\begin{tabular}{|c|c|c|c|c|c|}
\hline $\begin{array}{c}\text { Norma } \\
1\end{array}$ & & & & 89.94 & \\
$(8.56-$ & 19 & 62 & & & \\
$25.6)$ & & & & & \\
\hline
\end{tabular}

Table $\mathbf{V}$ shows low $\mathrm{FT}_{4}$ level compared to normal $\mathrm{FT}_{4}$ level is 31.33 times more likely to have recurrent pregnancy loss with 95\% CI 10.9189.94. thedifference was significant $(\mathrm{p}<0.05)$ between two group.

Table VI: Distribution of the study patients by mean $\mathrm{FT}_{4}$ level $(\mathrm{n}=134)$

\begin{tabular}{|c|c|c|c|}
\hline \multirow{2}{*}{$\mathrm{FT}_{4}$ level } & $\begin{array}{c}\text { Target group } \\
(\mathrm{n}=67)\end{array}$ & $\begin{array}{c}\text { Control group } \\
(\mathrm{n}=67)\end{array}$ & P value \\
\cline { 2 - 4 } & Mean \pm SE & Mean \pm SE & \\
\hline $\begin{array}{c}\mathrm{FT}_{4} \\
(\mathrm{fmol} / \mathrm{ml})\end{array}$ & $10.53 \pm 3.38$ & $18.67 \pm 4.81$ & \\
\hline $\begin{array}{c}\text { Range } \\
(\mathrm{min}, \\
\mathrm{max})\end{array}$ & $3.69,21.35$ & $7.83,25.6$ & \multirow{2}{*}{0.007} \\
\hline
\end{tabular}

Mean $\mathrm{FT}_{4}$ level was found $10.53 \pm 3.38 \mathrm{fmol} / \mathrm{ml}$ in cases and $18.67 \pm 4.81 \mathrm{fmol} / \mathrm{ml}$ in controls. The mean difference was statistically significant $(\mathrm{p}<0.05)$.

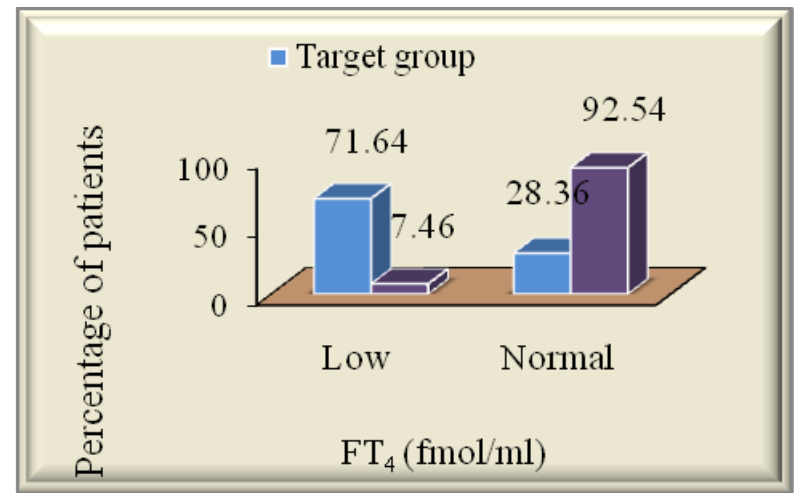

Figure 2: Bar diagram showing $\mathrm{FT}_{4}$ of the patients.
Table VII: Distribution of the study patients by thyroid antibody $(n=134)$

\begin{tabular}{|c|c|c|c|c|c|}
\hline $\begin{array}{l}\text { Anti } \\
\text { TPO } \\
\left(\mathrm{Ab}^{+}\right)\end{array}$ & $\begin{array}{l}\text { Target } \\
\text { group } \\
(\mathrm{n}=67)\end{array}$ & $\begin{array}{l}\text { Control } \\
\text { group } \\
(n=67)\end{array}$ & \multirow[t]{2}{*}{$\begin{array}{c}\mathrm{P} \\
\text { value }\end{array}$} & \multirow{2}{*}{$\begin{array}{l}\text { 95\% CI } \\
\text { (Lower, } \\
\text { Upper) }\end{array}$} & \multirow[t]{2}{*}{ OR } \\
\hline UIIII & $\begin{array}{c}\text { No. of } \\
\text { patients }\end{array}$ & $\begin{array}{c}\text { No. of } \\
\text { patients }\end{array}$ & & & \\
\hline$>15$ & 45 & 4 & \multirow[b]{2}{*}{0.001} & \multirow[b]{2}{*}{$\begin{array}{l}\text { 10.38, } \\
64.13\end{array}$} & \multirow[b]{2}{*}{32.21} \\
\hline $\begin{array}{c}\leq 15 \\
\text { (Norma } \\
\text { l) }\end{array}$ & 22 & 63 & & & \\
\hline
\end{tabular}

Table VII shows the more number of patients among cases had positive TPO-Antibody compared to controls. A subject with TPO Ab>15 $\mathrm{IU} / \mathrm{ml}$ vs TPO $\mathrm{Ab} \leq 15 \mathrm{IU} / \mathrm{ml}$ had 32.21 (95\% CI 10.38-64.13) times increase to developed recurrent pregnancy loss.

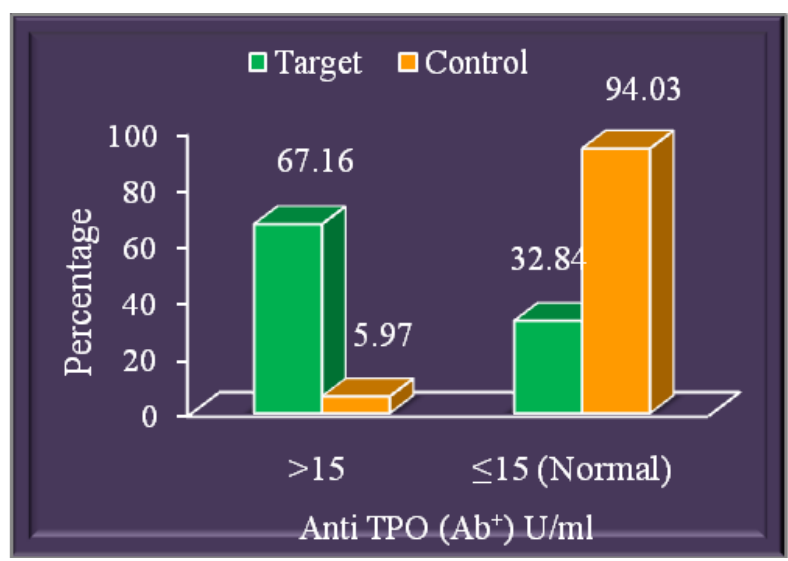

Figure 3: Bar diagram showing Anti TPO $\left(\mathrm{Ab}^{+}\right)$ of the patients. 
Table VIII: Status of thyroid antibody of miscarriage women (target) and control group $(n=134)$

\begin{tabular}{|c|c|c|c|c|c|}
\hline \multirow{2}{*}{$\begin{array}{l}\text { Antibod } \\
\text { y U/ml }\end{array}$} & $\begin{array}{l}\text { Target } \\
\text { group } \\
(\mathrm{n}=67)\end{array}$ & $\begin{array}{c}\text { Control } \\
\text { group } \\
(n=67)\end{array}$ & \multirow{2}{*}{$\begin{array}{c}\mathrm{P} \\
\text { valu } \\
\mathrm{e}\end{array}$} & \multirow{2}{*}{$\begin{array}{c}\text { 95\% CI } \\
\text { (Lower, } \\
\text { Upper) }\end{array}$} & \multirow{2}{*}{ OR } \\
\hline & $\begin{array}{l}\text { No. of } \\
\text { pts(\%) }\end{array}$ & $\begin{array}{l}\text { No. of } \\
\text { pts(\%) }\end{array}$ & & & \\
\hline $\begin{array}{l}\mathrm{TPO}^{-} \\
\mathrm{Ab}^{+} \\
\text {(positiv } \\
\text { e) }\end{array}$ & $\begin{array}{c}55 \\
(82.09 \\
\%)\end{array}$ & $\begin{array}{c}21 \\
(31 . .34 \%)\end{array}$ & \multirow{2}{*}{$\begin{array}{c}0.00 \\
1\end{array}$} & \multirow{2}{*}{$\begin{array}{l}4.47 \\
22.57\end{array}$} & \multirow{2}{*}{10.04} \\
\hline $\begin{array}{c}\text { TPO- } \\
\text { Ab }^{-} \\
\text {(negativ } \\
\text { e) }\end{array}$ & $\begin{array}{c}12 \\
(17.91 \\
\%)\end{array}$ & $\begin{array}{c}46 \\
(68.66 \%)\end{array}$ & & & \\
\hline
\end{tabular}

Table VIII shows the cases had higher percentage (82.09\%) of positive antibody compared to controls (31.34\%).

Positive TPO Ab compared to negative TPO Ab is 10 times more likely to have recurrent pregnancy loss with 95\% CI 4.47-22.57. The difference was significant $(\mathrm{p}<0.05)$ between two groups.

\section{Discussion}

This is a case control study carried out with an aim to find out the association of thyroid autoimmunity with recurrent pregnancy loss. The study population consisted of pregnant women with a history of recurrent pregnancy loss during first trimester. Depending on the increased necessity of the thyroid gland for normal development, growth and metabolic homeostasis during pregnancy and fetal life, changes associated with pregnancy require an increased availability of thyroid hormones by $40 \%$ to $100 \%$ in order to meet the needs of mother and fetus during pregnancy. ${ }^{13}$

A number of researches have been published concerning the relation of thyroid autoimmunity and miscarriage. All studies are not easily comparable due to the different selection criteria employed for specific aims for each study, but most studies have shown a significant positive association between the presence of thyroid autoantibodies and miscarriage rate. ${ }^{12}$ It was suggested that those autoantibodies, which can also be higher in the euthyroid patients, may produce a threat for miscarriage in the subsequent pregnancy. Thyroid peroxidase antibodies target the thyroid peroxidase enzyme that assists in the production and metabolism of thyroid hormone.

Although they are widely seen in autoimmune thyroid disorders, thyroid peroxidase antibodies are not necessarily a sign of disease. In the normal healthy population, when TPO antibodies are accompanied by a higher TSH level $(>2.0 \mathrm{mu} / \mathrm{L})$ they suggest an increased risk for developing Hashimoto's thyroiditis ${ }^{14}$. In spite of many studies available regarding the physiological changes in the thyroid function during pregnancy, it is uncertain if functional disorders of the thyroid gland play a role in the etiology of spontaneous miscarriages. However, the present study was trying to evaluate both thyroid hormones and thyroid antibodies as causative agent for miscarriage. The results of present study (TableVI) showed decrease concentration of $\mathrm{FT}_{4}$ level, decrease of $\mathrm{FT}_{4}$ level may be due to non-pituitary stimulation of thyroid hormone secretion (hCG concentration). ${ }^{15}$

The higher TSH values (Table-III) that reported in the recurrent miscarriage group means that the $\mathrm{TH}$ in blood circulation is not high enough to stop the stimulation of the hypothalamus of release TRH to the anterior pituitary to inhibit the stimulation of the synthesis and secretion of TSH. Consequently the TH is not sufficient to meet the need of both mother and fetus resulting in termination of the pregnancy. ${ }^{16,17}$ The low levels of TSH in miscarriage women is associated with small percentage of inereasedTT 4 levels and high percentage of normal $\mathrm{FT}_{4}$ levels so most of miscarriage women are euthyroid according to the evaluation strategy of low serum TSH level. ${ }^{18}$ This may be due to either IDD which diminishes the biosynthesis of thyroid hormones or to the lack of response of estrogen which affect the level of TBG, that is, the H-P-T axis work as if the women are not pregnant.

Euthyroid women in early gestational stages tend to have a reduced thyroid function reserve and 
they have an increased risk for obstetrical complications such as miscarriage and premature delivery. ${ }^{19}$

Most of the studies reported that there was significant negative correlation between the T4 and TSH levels in normal pregnancy. ${ }^{20,21}$ Free thyroid hormones in both normal pregnant and recurrent miscarriage women were within the normal levels and this finding was disagreed with some study. ${ }^{22}$

The present study is indicating positive thyroid antibodies in both groups. The control pregnant women with positive thyroid antibodies can reach the term and have babies due to the suppression in the level of the TSH through the feedback mechanism.

Thyroid hormones are essential for the developing fetus. Hence a pregnant women needs thyroxin more than non-pregnant lady to provide $\mathrm{T}_{4}$ to both herself and her developing fetus. It is advisable to suggest thyroid investigation to the pregnant women with history of recurrent miscarriage as soon as possible after knowing they are pregnant. Management of thyroid diseases during pregnancy required special considerations because pregnancy induces major changes in thyroid function, and maternal thyroid disease can have adverse effects on the pregnancy and the fetus.

\section{Conclusion:}

Most of the women with recurrent miscarriage were euthyroid. The TSH levels were found to be normal in miscarriage women compared with healthy pregnant women. The feedback mechanism of thyroid-pituitary glands is profound or not properly works in women with recurrent miscarriage. The mean serum concentration of $\mathrm{TPO}-\mathrm{Ab}$ (positive) in miscarriage women was significantly higher than mean concentration of TPO-Ab(positive) in healthy pregnant women. The thyroid antibodies can only affect pregnant women when there serum TSH level is relatively within actual normal range and free $\mathrm{T}_{4}$ level in miscarriage women does not affected by the decreased TSH values. Pregnant women can reach term and have babies when their TSH levels are relatively lower.

\section{References}

1. Hassold T, Abruzzo M, Adkins K, Griffin D, Merrill $M$, et al. Human Aneuploidy; Incidence, origin and etiology. Environ Mol Mutagen, 1996; 28:167-75.

2. Carrington B, Sacks G, Regan L. Recurrent miscarriage: pathophysiology and outcome. Current Opinion in Obstetrics \& Gynecology, 2005 17:591597.

3. Steven R. Bayer, M leahciM. replA, S nalA. ecitcarP rof yteicoS naciremA eht fo eettimmoc enicideM evitcudorpeR. dna ytilitrefni fo noitinifeD ercurrent pregnancy loss. Fertility and Sterility, 2008; 90:560.

4. Singh A, Dantas ZN, Stone SC, Asch RH. Presence of thyroid antibodies in early reproductive failure: biochemical versus clinical pregnancies. FertilSteril1995; 63:277-281.

5. Bussen S, Steck T. Thyroid autoantibodies in euthyroid non-pregnant women with recurrent spontaneous abortion. Hum Reprod1995; 10:29382940.

6. Vaquero E, Lazzarine $N$, Carolis D, Valensise $H$, Moretti $\mathrm{C}$, et al. Mild thyroid abnormalities and recurrent spontaneous abortion: diagnostic and therapeutical approach. Am J Reprod Immunol 2000; 43:204-208.

7. Kalro BN, 2003. Impaired infertility caused by endocrine dysfunction in women. Endocrinol Metab Clin North Am2003; 32:573-92.

8. Canaris GJ, Manowitz NR, Mayor G, Ridgway EC. The Colorado thyroid disease prevalence study. Arch Intern Med 2000; 160:526-34.

9. Hollowell JG, Staehling NW, Flanders WD, Hannon WH, Gunter EW. Serum TSH, $\mathrm{T}_{4}$ and thyroid antibodies in the United States population (19881994): National Health and Nutrition Examination Survey (NHANES III). J Clin Endocrinol Metab 2002; 87:489-99.

10. Kennedy RL, Malabu UH, Jarrod G, Nigam $P$, Kannan K. Thyroid function and beyond. J Obstet Gynaecol 2010; 30:774-83.

11. Abbassi- Ghanavati M, 2011. Thyroid autoantibodies and pregnancy outcome. Clin Obster Gynecol 2011; 54:499-505.

12. Kaprara A, Krassas GE. Thyroid autoimmunity and miscarriage. Hormones (Athens) 2008; 7:294-302.

13. Smallridge R C, Glinoer D, Hollowell JG, Brent G. Thyroid function inside and outside of pregnancy: What do we know and what don't we know? Thyroid, 2005; 15: 54-9. 
14. Basal As., Hayman GR. Grave's disease associated with chronic idiopathic urticaria: 2 case reports, Jinvestig Allergel ClinImmunol 2009; 19:546.

15. Dönmez M., Tolga Sisli, AlevAtis, Yavuz Aydin. Spontaneous abortion and thyroid function, perinatal journal 2005; vol: 13;110-113.

16. Zigman Jeffrey M., Shmuel E. Cohen and Jeffrey R. Garber. Impact of Thyroxine-Binding globulin bon thyroid hormone Economy during pregnancy 2003; 13:1169-1175.

17. Glinoer D. The regulation of thyroid function during normal pregnancy: Importance of the iodine nutrition status. Daniel best practice \& Research Clinical Endocrinology \& Metabolism, 2004; 18: 133-152.

18. Kasper DL, Braunwald E, Fauci AS, Hawere SL, Longo DL, Jameson JL. (2005). Harrison's principles of internal medicine. $16^{\text {th }}$ edition,
McGraw-Hill companies USA. Chapter 320 (21042126).

19. Stagnaro-Green A.(2009). Maternal thyroid disease and preterm delivery. J ClinEndocrinolMetab2009; 94: 21-5.

20. Glinoer D. The regulation of thyroid function in pregnancy: Pathways of endocrine adaptation from physiology to pathology. Endocrine Reviews; 1997; 18:404-433.

21. Rodien Patrice, Nicola Jorden, Anne LefeÁvre, Julien Royer, Claudine vasseur, FreÂdeÂrique Savanger, AlineBourdelot and Vincent Rohmer (2004). Abnormal stimulation of the thyrotropin receptor during gestation. Human Reproduction update, 2004; 10: 95-105.

22. Maruo T, Katayama K, Matuso $\mathrm{H}$,Anwer $\mathrm{M}$, Mochizuki M. Modification of endocrine function of trophoblast by thyroid hormone. Nippon santafujinica Gakkai Zashi Akta Obstetricaet Gynaecologica Japonica 1991; 43: 1533-38.

All correspondence to -

Dr. Sharmin Sultana Medical Officer

Department of Obstetrics and Gynaecology Rajshahi Medical College Hospital E-mail :dr.sharminsultana80@gmail.com 